\title{
PROSPEK PENGEMBANGAN ENERGI SURYA UNTUK KEBUTUHAN LISTRIK DI INDONESIA
}

\author{
Valdi Rizki Yandri \\ Politeknik Universitas Andalas, Kampus Unand Limau Manis Padang 25163 \\ Email : valdi_rizki@yahoo.com)
}

\begin{abstract}
Energy has important meaning in social and economics achievement to continously development and support to national economics activities. Energy consumption in Indonesia increases rapidly parallel with economics engagement and people growth. To supply energy requirement, renewable energy source should be developed. Renewable energy potency like solar energy hasn't been used for big scale although Indonesia has big energy potency.

Indonesia be included on tropical area which is exposed sun radiance almost year. It means solar energy has good prospects to be developed in Indonesia. Solar energy is one kind of energy which is gotten by converting sun calor energy to another type of energy. Solar energy can be used in form solar cell for electrical power plant. The utilization of solar cell can help people who lives on isolated area which is far from electrical network to use electrical energy.
\end{abstract}

Keyword : Solar cell, energy consumption, power plant

\section{ENERGI SURYA}

Energi surya adalah energi yang didapat dengan mengubah energi panas surya (matahari) melalui peralatan tertentu menjadi sumber daya dalam bentuk lain. Energi surya menjadi salah satu sumber pembangkit daya selain air, uap,angin, biogas, batu bara, dan minyak bumi.

Teknik pemanfaatan energi surya mulai muncul pada tahun 1839, ditemukan oleh A.C. Becquerel. Ia menggunakan kristal silikon untuk mengkonversi radiasi matahari, namun sampai tahun 1955 metode itu belum banyak dikembangkan. Selama kurun waktu lebih dari satu abad itu, sumber energi yang banyak digunakan adalah minyak bumi dan batu bara.

Upaya pengembangan kembali cara memanfaatkan energi surya baru muncul lagi pada tahun 1958. Sel silikon yang dipergunakan untuk mengubah energi surya menjadi sumber daya mulai diperhitungkan sebagai metode baru, karena dapat digunakan sebagai sumber daya bagi satelit angkasa luar.

Energi surya telah banyak diterapkan dalam kehidupan sehari-hari. Beberapa aplikasi energi surya adalah:

1. Pencahayaan bertenaga surya,

2. Pemanasan bertenaga surya, untuk memanaskan air, memanaskan dan mendinginkan ruangan,

3. Desalinisasi dan desinfektifikasi,

4. Untuk memasak, dengan menggunakan kompor tenaga surya.

Energi surya merupakan salah satu energi yang sedang giat dikembangkan saat ini oleh Pemerintah Indonesia karena sebagai negara tropis, Indonesia memiliki potensi energi surya yang besar. 
Berdasarkan data penyinaran matahari yang dihimpun dari 18 lokasi di Indonesia, radiasi surya di Indonesia dapat diklasifikasikan berturut-turut sebagai berikut :

1. Kawasan Barat Indonesia (KBI) dengan distribusi penyinaran sekitar 4,5 $\mathrm{kWh} / \mathrm{m}^{2} /$ hari dengan variasi bulanan $10 \%$

2. Kawasan Timur Indonesia (KTI) dengan distribusi penyinaran sekitar 5,1 $\mathrm{kWh} / \mathrm{m}^{2} /$ hari dengan variasi bulanan sekitar $9 \%$.

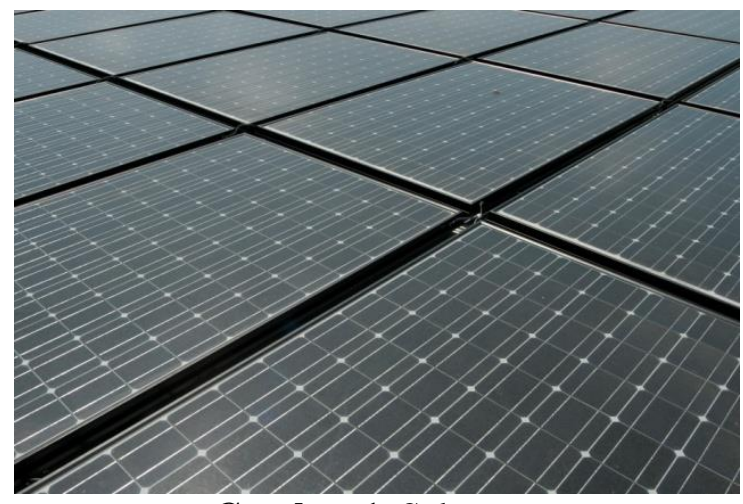

Gambar 1. Sel surya

\section{TEKNOLOGI ENERGI SURYA FOTOVOLTAIK}

Salah satu cara penyediaan energi listrik alternatif yang siap untuk diterapkan secara massal saat ini adalah Sistem Energi Surya Fotovoltaik (SESF) atau secara umum dikenal sebagai Pembangkit Listrik Tenaga Surya Fotovoltaik (PLTS Fotovoltaik).

Sebutan SESF merupakan istilah yang telah dibakukan oleh pemerintah yang digunakan untuk mengidentifikasikan suatu sistem pembangkit energi yang memanfaatkan energi matahari dan menggunakan teknologi fotovoltatik. Jika dibandingkan energi listrik konvensional, SESF terkesan rumit, mahal dan sulit dioperasikan.

Namun demikian, berdasarkan pengalaman operasional lebih dari 15 tahun di beberapa kawasan di Indonesia, SESF merupakan suatu sistem yang mudah dalam pengoperasiannya, handal dan memerlukan biaya pemeliharaan dan operasi yang rendah menjadikan SESF mampu bersaing dengan teknologi konvensional pada sebagain besar kondisi wilayah Indonesia yang terdiri dari pulau-pulau kecil dan tidak terjangkau oleh jaringan PLN dan tergolong sebagai kawasan terpencil.

Selain itu, SESF merupakan suatu teknologi yang bersih dan tidak mencemari lingkungan. Beberapa kondisi yang sesuai untuk penggunaan SESF antara lain pada permukiman desa terpencil, lokasi transmigrasi dan perkebunan baik untuk penerangan rumah maupun fasilitas umum. Akan tetapi, sesuai dengan perkembangan jaman, saat ini di negara-negara maju, penerapan SESF telah banyak digunakan untuk suplai energi listrik di gedung-gedung dan perumahan di kota besar.

Pada umumnya, modul fotovoltaik dipasarkan dengan kapasitas 50 Watt-peak (Wp) dan kelipatannya. Unit satuan Watt-peak adalah satuan daya (Watt) yang dapat dibangkitkan oleh modul fotovoltaik dalam keadaan standar uji (Standard Test Condition - STC). Efisiensi pembangkitan energi listrik yang dihasilkan modul fotovoltaik pada skala komersial saat ini adalah $14-15 \%$. 


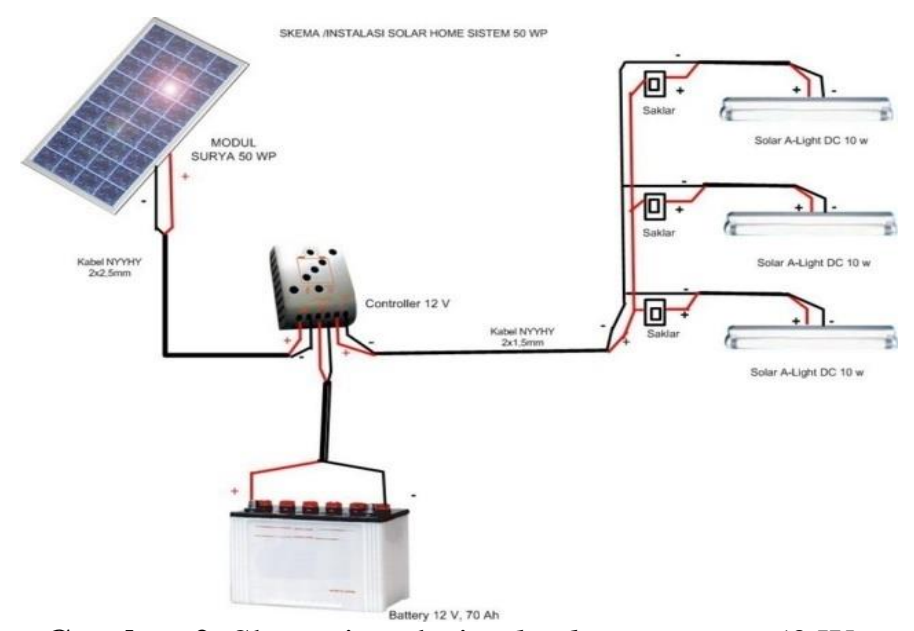

Gambar 2. Skema instalasi solar home system $50 \mathrm{Wp}$

Komponen utama suatu SESF adalah :

1. Sel fotovolatik yang mengubah radiasi matahari menjadi listrik secara langsung. Produk akhir dari modul fotovoltaik menyerupai bentuk lembaran kaca dengan ketebalan 6-8 mm,

2. Balance of System (BOS) yang meliputi controller, inverter, kerangka modul peralatan listrik, seperti kabel dan stop kontak,

3. Unit penyimpan energi (baterai),

4. Peralatan penunjang lainnya, seperti inverter untuk pompa, sistem terpusat dan sistem hybrid.

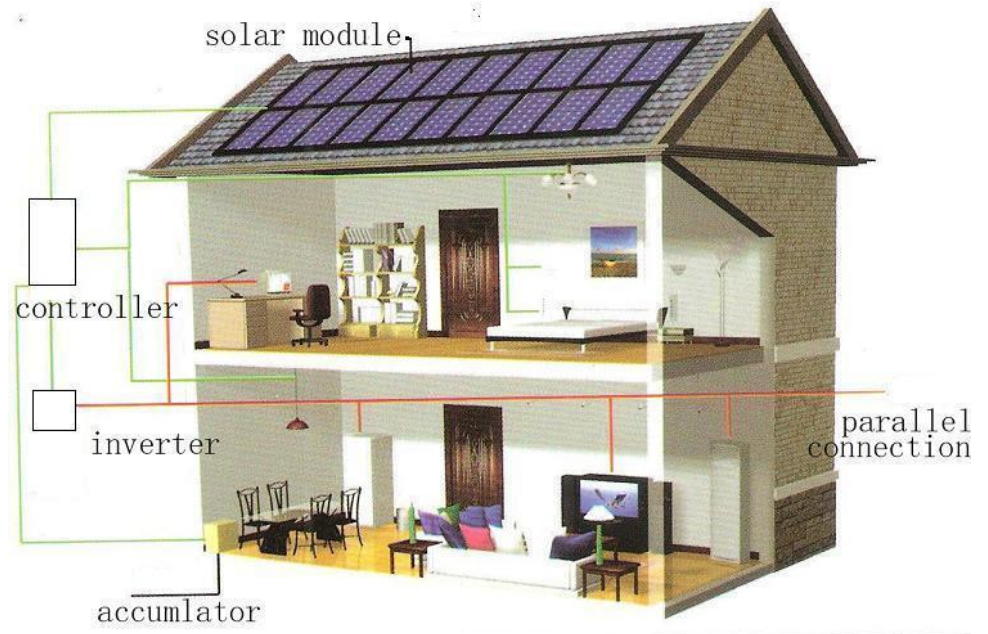

Gambar 3. Model penggunaan SESF untuk keperluan rumah tangga

Untuk pengembangan energi surya fotovoltaik di Indonesia, dapat digunakan berbagai strategi berikut:

1. Mendorong pemanfaatan SESF secara terpadu, untuk keperluan penerangan (konsumtif) dan kegiatan produktif,

2. Mengembangkan pemanfaatan SESF di perdesaan dan perkotaan,

3. Mendorong komersialisasi SESF dengan melibatkan pihak swasta,

4. Mengembangkan industri SESF dalam negeri berorientasi ekspor,

5. Mendorong terciptanya sistem dan pola pendanaan yang efisien dengan melibatkan dunia perbankan. 
Program yang telah dilakukan oleh pemerintah Indonesia berkaitan dengan energi surya fotovoltaik adalah :

1. Mengembangkan SESF untuk program listrik perdesaan, khususnya untuk memenuhi kebutuhan listrik di daerah yang jauh dari jangkauan listrik PLN,

2. Mengganti seluruh atau sebagian posokan listrik bagi pelanggan sosial kecil dan rumah tangga kecil dengan SESF.

Selain itu, pola pengembangan yang dapat dilaksanakan juga bisa berupa :

1. Memenuhi semua kebutuhan listrik untuk pelanggan S1 (Sosial 1) dengan batas daya 220 VA dan 450 VA,

2. Memenuhi 50\% kebutuhan listrik untuk pelanggan S2 (Sosial 2) dengan batas daya $900 \mathrm{VA}$,

3. Memenuhi 50\% kebutuhan listrik untuk pelanggan R1 dengan batas daya $450 \mathrm{VA}$.

4. Melaksanakan kerjasama dengan instansi pendidikan untuk penelitian SESF skala besar.

\section{TEKNOLOGI ENERGI SURYA TERMAL}

Sebelumnya, pemanfaatan energi surya termal di Indonesia masih dilakukan secara tradisional. Para petani dan nelayan di Indonesia memanfaatkan energi surya untuk mengeringkan hasil pertanian dan perikanan secara langsung.

Sebenarnya, pemanfaatan energi surya termal dapat dikembangkan untuk berbagai keperluan, seperti:

1. Pengering pasca panen,

2. Pemasak / kompor,

3. Pompa air,

4. Penyuling air.

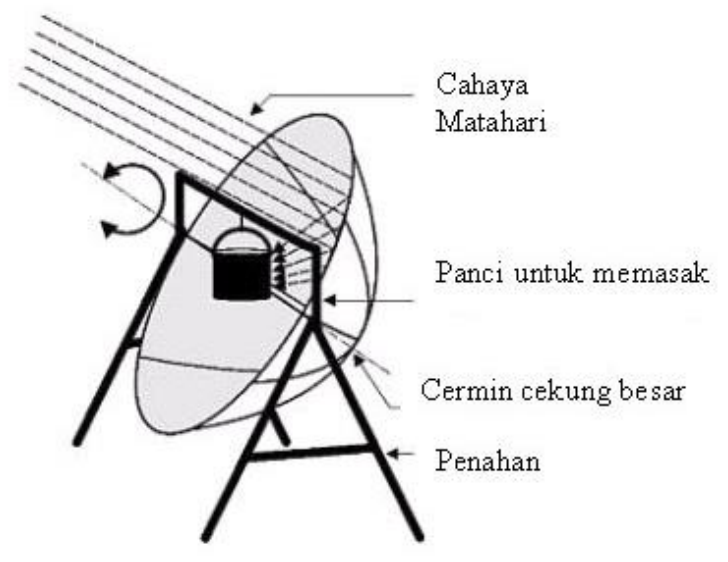

Gambar 4. Kompor matahari

Dalam pengembangan energi surya termal di Indonesia, dapat digunakan beberapa strategi berikut :

1. Mengarahkan pemanfaatan energi surya termal untuk kegiatan produktif, khususnya untuk kegiatan agro industri,

2. Mendorong keterlibatan swasta dalam pengembangan teknologi surya termal,

3. Mendorong terciptanya sistem dan pola pendanaan yang efektif, 
Program pengembangan energi surya yang dapat dilakukan oleh pemerintah adalah :

1. Melakukan inventarisasi, identifikasi dan pemetaan potensi serta aplikasi teknologi fototermik secara berkelanjutan,

2. Melakukan diseminasi dan alih teknologi dari pihak pengembang kepada pemakai (agroindustri, gedung komersial dan lain-lain) dan produsen nasional (manufaktur, bengkel mekanik dan lain-lain) melalui forum komunikasi, pendidikan dan pelatihan dan proyek-proyek percontohan,

3. Melaksanakan standardisasi nasional komponen dan sistem teknologi fototermik,

4. Mengkaji skema pembiayaan dalam rangka pengembangan manufaktur nasional,

5. Meningkatkan kegiatan penelitian dan pengembangan manufkatur nasional,

6. Meningkatkan kegiatan penelitian dan pengembangan untuk berbagai teknologi fototermik

\section{PEMANFAATAN ENERGI SURYA DI WILAYAH JAWA BARAT}

Salah satu wilayah di Indonesia yang telah mengembangkan pemanfaatan energi surya untuk sumber energi listrik adalah Jawa Barat. Wilayah Jawa Barat bagian utara seperti Kabupaten Indramayu, Kabupaten Majalengka dan Kabupaten Kuningan termasuk bagian wilayah yang masih rendah rasio elektrifikasinya. Sejak tahun 2003 sampai dengan 2009, sel surya telah dimanfaatkan di 15 desa seperti ditunjukkan pada tabel 1 .

Tabel 1. Data Lokasi Pemanfaatan Sel Surya di Jawa Barat

\begin{tabular}{|l|c|c|}
\hline Kabupaten & $\begin{array}{c}\text { Jumlah KK } \\
\text { yang dilayani }\end{array}$ & Tahun \\
\hline Indramayu & 25 & \\
Majalengka & 23 & 2003 \\
Tasikmalaya & 25 & \\
\hline Majalengka & 55 & 2004 \\
Indramayu & 5 & \\
\hline Cianjur & 10 & 2005 \\
Majalengka & 40 & \\
\hline Majalengka & 32 & \\
Indramayu & 57 & \\
Cianjur & 100 & 2006 \\
Kuningan & 3 & \\
Indramayu & 100 & \\
Cianjur & 100 & \\
\hline Cianjur & 200 & 2007 \\
\hline Indramayu & 150 & 2008 \\
\hline Indramayu & 354 & 2009 \\
\hline
\end{tabular}

\section{DAFTAR PUSTAKA}

1. Keputusan Menteri ESDM nomor 2 tahun 2004. Kebijakan Pengembangan Energi Terbarukan Dan Konservasi Energi (Pengembangan Energi Hijau). Jakarta.

2. Krane, Kenneth S. 2002. Fisika Modern. Jakarta: UI Press. Beaser, Arhtur.

3. Peraturan Presiden Indonesia nomor 5 tahun 2006. Peraturan Energi Nasional. Jakarta. 
4. Pracesna, Daficka. 2004. Pembuatan dan Karakterisasi Prototipe Sel Surya Nano Kristal $\mathrm{TiO}_{2}$ tersensitisasi Dye menggunakan $\mathrm{Cul}$ sebagai Elektrolit $\left(\mathrm{TiO}_{2} / \mathrm{Dye} / \mathrm{Cul}\right)$. Bogor : Institut Pertanian Bogor.

5. Sugandi, Gandi. 2001. Analisa Biaya Produksi Pembuatan Sel Surya dengan Metoda Screen Printing Kapasitas 5000 per bulan. Bandung : Lembaga Ilmu Pengetahuan Indonesia.

6. Undang-undang nomor 30 tahun 2007. Energi. Jakarta.

7. Van Overstraeten RJ, RP Mertens. 2005. Technology and Use of Photovoltaics. England : Adam Higler Ltd.

8. http://www.kamase.org/?p=279

9. http://puslit2.petra.ac.id/ejournal/

10. http://digilib.its.ac.id/public/ITS-Undergraduate 